\title{
Influence and Complementarity of Follow-on Managerial Innovations within a Public Organization
}

\author{
Christophe Favoreu, Toulouse Business School, Toulouse, France \\ Christophe Maurel, Université d'Angers, Angers, France \\ David Carassus, Université de Pau et des Pays de l'Adour, IAE Pau-Bayonne, CREG, Pau, France \\ Pierre Marin, Université de Pau et des Pays de l'Adour, IAE Pau-Bayonne, CREG, Pau, France
}

\begin{abstract}
The objective of this research is to explore the relations between different categories of managerial innovations in public organizations. This paper aims to characterize the nature of the links between the implementation of an innovation and the subsequent adoption of a second, "follow-on" innovation. The research, which integrates the specific dimension of public managerial innovation, endeavours to enrich the research and the literature on the determinants of innovation dynamics in public organizations. Using two case studies of French local government authorities, this research highlights the direct and indirect effects and show how managerial innovations positively influence the future innovation capability of public organizations.
\end{abstract}

Keywords: innovation dynamics, managerial innovation, public organization, local government 


\section{INTRODUCTION}

In the context of today's increasingly complex and constrained financial and budgetary environment, innovation is the primary means for improving the effectiveness and efficiency of public policies (Damanpour \& Schneider, 2006; Sorensen \& Torfing., 2011, Arundel et al., 2015) and, more generally, of the quality of public services (Boyne et al, 2005; Jung \& Lee, 2016). Indeed, on a global scale, the multiplication of national and local structures and programmes aimed at fostering and diffusing public innovation can be observed (Walker, 2006; Walker \& Boyne, 2006; Arundel et al, 2015). Among the different types of innovation, public organizations in their vast majority resort to organizational and managerial innovations bearing on management techniques and modes of internal functioning and organization (De Vries et al., 2016). The multiplicity of experiments in management and performance measurement (Rivenbark et al., 2016), strategic planning (Poister, 2010), balanced scorecards, mutualisation and agencification testifies to this vogue, as does the corresponding academic research. The enthusiasm this movement has generated, however, and the hopes placed in the managerial innovations it embraces, contrast with the actual results obtained. Indeed, a number of studies report a high rate of failure or dissatisfaction when it comes to managerial innovations, performance-based management being one example (Yang \& Hsieh 2007; Van Dooren \& Thijs 2010; Hijal-Moghrabi, 2017). In the public sector these innovations, despite their popularity, often fail to produce significant results and so prove short-lived. Moreover, even between public organizations of the same type and/or in the same country, there are differences in the pace and degree of innovation (Bouckaert \& Halligan, 2008).

Faced with this problematic situation, public management research has taken up the challenge of understanding the processes of public innovation. Even though research on the determinants of public innovation has increased (de Vries et al., 2016), such studies are still few in number. Moreover, two elements essential for understanding the processes of public innovation are often passed over. One is managerial innovation. Indeed, the distinctive characteristics and relatively heterogeneous nature of managerial innovation (Damanpour \& Aravind, 2012; Mol \& Birkinshaw, 2014) render problematic the transposition to it of knowledge derived from technological and other 
types of innovation. According to Damanpour (2014), managerial innovation's distinctive characteristics mean that it cannot be assimilated, conceptually or operationally, to other forms of innovation. It is therefore unwise to assume that the dynamics of managerial innovation are similar to those of other types of innovation. The other element is the interdependencies and influences between managerial innovations implemented over time within the same organization. Indeed, because they usually adopt a compartmentalized approach, they tend to ignore the potential links between different forms of innovation. This disregard is all the more problematic in that an increasing number of studies, mostly of private-sector organizations, argue that different forms of innovation are in fact interdependent and therefore, in studying managerial innovation, an integrative, evolutionary approach is pertinent (Walker, 2007; Damanpour, 2014; Lam, 2005; Bocquet \& Dubouloz, 2015). This research therefore affirms the relevance of analyzing and characterizing, in the public-sector, the relations of influence between different types of managerial innovation.

Thus, the following question appears: can the differences in innovation between public organizations be explained by the dynamics of past innovations in these same organizations, thereby making inadequate the traditional explanation that attributes these differences to organizational and environmental factors? This study sets out to explore and analyze the causal links and relations of reciprocal or recursive influence between different types of managerial innovation enacted within the same organization. More precisely, the paper aims to characterize and analyze the nature of the links between the implementation of a managerial innovation and the adoption, in the same organization, of a subsequent, or "follow-on", managerial innovation.

Part one defines the concept of public-sector managerial innovation and provides an overview of possible links between innovations enacted in the same organization. On the basis of existing theory and research, a number of particular links are then postulated. The second part examines these links in the light of our fieldwork findings and studies them in greater depth via a multi-site case study. Finally, the third part discusses the nature of the causal links before concluding with theoretical considerations and outlining some future research directions. 


\section{MANAGERIAL INNOVATION AND THE DETERMINANTS OF INNOVATION IN THE PUBLIC SECTOR}

This section defines the various components of managerial innovation, drawing on the typology by Mol \& Birkinshaw (2014), and specify its particularities vis-a-vis other types of public innovation. Then it highlights the potential influence of a determinant of innovation hitherto neglected in the literature: antecedent managerial innovation.

\subsection{The concept of managerial innovation}

If academic research today considers managerial innovation as a specific form of innovation with its own identity ${ }^{1}$, the number of studies devoted to it are few compared to the volume of research on other types of innovation (Damanpour, 2014; Vaccaro et al, 2012; Volberda et al., 2013, 2014). Moreover, the research presents contrasting theories, especially as regards the determinants and antecedents of this type of innovation (Sapprasert \& Clausen, 2012, De Vries et al, 2016). Managerial innovation ${ }^{2}$ may be defined as the adoption of methods of management, organization and operating that are new for an organization and that aim to improve organizational performance (Walker, 2006; Damanpour, 1987; Mol \& Birkinsaw, 2014). According to the interpretive approach adopted (Van de Ven \& Rogers, 1988), standards of newness are not absolute (they are not measured against identical referential frameworks) but instead are relative to a particular organization and its usual practices. Managerial innovation covers a wide range of objects that can nevertheless be grouped into two generic categories: innovations to do with organization and structure, and innovations to do with managerial techniques and processes. Managerial innovations can also be differentiated according to their intensity, defined as the impact of the innovation on the organization, on its dominant organizational paradigms and its competencies (Mol \& Birkinshaw, 2014). According to their intensity, they lead in varying degrees to a transformation of the organization, of its resource management and internal activities. By this criterion comprehensive managerial innovations, which have a strong organizational

${ }^{1}$ Following Rogers (2003), De Lancer Julnes (2008) and Damanpour \& Schneider (2008), innovation is defined as the generation and adoption by an organization of new ideas and behaviours.

${ }^{2}$ Also known as organizational, administrative or management innovation. 
impact, can be distinguished from incremental ones, which have relatively limited organizational impact. These two descriptive dimensions allow to distinguish the four forms of managerial innovation that will be referred in the empirical study. (See table 1)

\begin{tabular}{|c|c|c|c|}
\hline \multicolumn{2}{|c|}{} & \multicolumn{2}{|c|}{ Nature of the managerial innovation } \\
\cline { 3 - 4 } & & $\begin{array}{c}\text { Oriented toward } \\
\text { structure/mode of } \\
\text { organization }\end{array}$ & $\begin{array}{c}\text { Oriented toward process } \\
\text { and managerial tools }\end{array}$ \\
\hline \multirow{2}{*}{ Extent of change } & $\begin{array}{c}\text { Includes all parts of the } \\
\text { organization }\end{array}$ & $\begin{array}{c}\text { Comprehensive } \\
\text { structural innovation }\end{array}$ & $\begin{array}{c}\text { Comprehensive } \\
\text { process innovation }\end{array}$ \\
\cline { 2 - 4 } & $\begin{array}{c}\text { Limited to specific parts of } \\
\text { the organization }\end{array}$ & $\begin{array}{c}\text { Local structural } \\
\text { innovation }\end{array}$ & $\begin{array}{c}\text { Local process } \\
\text { innovation }\end{array}$ \\
\hline
\end{tabular}

Table 1: Typology of managerial innovations according to their nature and impact

Managerial innovation as a practice and as an object of research faces a paradoxical situation in the public sector. Indeed, even though it represents an increasing share of public innovation, and despite its positive influence on organizational performance (as a number of research studies suggest [Gonzalez et al., 2013, Damanpour, 2014]), it has long been considered secondary and remains relatively neglected by academic research (De Vries et al., 2016). The great majority of research studies have concerned technological innovation ${ }^{3}$ related to processes or products, and most models, theories and hypotheses have been developed on the basis of empirical studies focused on this one type of innovation. In both the public and private sectors, managerial innovations have usually been studied through the lens of technological innovation (Birkinshaw et al., 2008; Le Roy et al., 2013). However, to assume that theories and models derived from the study of technological innovation can be transposed to managerial innovation is problematic, all the more so in that numerous research studies have pointed out major differences between these two forms of innovation (Damanpour, 2014; Tether \& Tajar, 2008). Indeed, the tacit knowledge characteristic of managerial innovations (Birkinshaw et al., 2008), their lower transferability due to their identification with particular individuals, their systemic character (the ramifications of their influence on other organizational elements) and their impact on the organization's social system (Damanpour, 2014) are all factors

\footnotetext{
${ }^{3}$ Technological innovation: when a new technological competence that concerns the organization's main business or activity is deployed.
} 
that make their diffusion and implementation much more complex than is the case for technological innovations. This is a key distinguishing characteristic of managerial innovations. Indeed, in contrast to technological innovations, where transformations mainly concern the technical system of the organization, managerial innovations go hand-in-hand with changes in internal operating methods and social interactions (Walker, 2006). By modifying hierarchical relations and decision-making procedures, they inevitably affect actors' zones of power and influence as well as internal balances and social arrangements (Walker et al., 2015; Lux \& Petit, 2016). Moreover, by throwing into question not only the practices but also the values and representations associated with organizational routines (Ayerbe \& Fonrouge, 2005), managerial innovations are liable to upset an organization's system of social norms and rules. This risk of conflict with the internal social system is all the greater in the public sector in that most managerial innovations are derived from the private sector or the principles of New Public Management (Scupola \& Zanfei, 2016); as such, they upset the public sector's traditional bureaucratic and hierarchical mode of management and the organizational behaviours and routines (stability, rules-based conformity, etc.) associated with it ${ }^{4}$. The distinctive characteristics of managerial innovation, then, together with the specific features of the public sector, confirm the relevance of the research problem.

\subsection{Determinants of innovation dynamics in public organizations}

Studying the determinants of managerial innovation implies analyzing the factors that influence it during the different phases of its development. Indeed, innovation is generally conceptualized as a multiphase process composed of four main stages: awareness, adoption, implementation and institutionalization/routinization (Damanpour \& Schneider, 2006). This paper, since the aim is to understand how the implementation of one innovation can influence the adoption of a subsequent, follow-on one, is focused on the first two phases.

Innovation can also be understood as a multidimensional phenomenon whose dynamics are influenced by a diversity of factors both internal and external to the organization. Research on antecedents to innovation generally considers three groups of factors: environmental and contextual; organizational; and intrinsic innovation

\footnotetext{
${ }^{4}$ Managerial innovations with a mainly private focus induce a transformation of the administrative organization's behaviours and values and of its modes of internal interaction (Bouckaert \& Halligan, 2008).
} 
characteristics). In the public sector, most studies have focused on the organizational or environmental determinants (De Vries et al., 2016; Walker et al., 2015)). Damanpour \& Schneider (2006, 2008), for example, have highlighted the positive influence on local governments' innovation decisions of environmental factors such as economic growth, population growth, the tax base and the size of the community in which the organization is located. These studies draw on contingency theory, which considers innovation to be an adaptation of an organization's structures to changes in the environment. Innovation is thus seen as a response to change in terms of opportunities and constraints on development (Walker, 2006). Within the category of environmental factors, numerous studies, drawing on new institutional theory (DiMaggio \& Powell, 1983; Shenhav \& Weitz, 2000), have focused on characterizing the influence of institutional pressures and the political context on innovation choices (De Vries et al., 2016; Dubouloz \& Mattelin Pierrard, 2017; Damanpour, 2014). Mimetic behaviour and the quest for legitimacy are said to largely explain the dynamics of innovation in the public sector. A second group of studies focuses on the influence of a variety of organizational characteristics, including size, the nature of the structure (organic or mechanistic), communication, resources, intra-organizational relations, and integration (De Vries et al., 2016). In this category of determinants, the role and characteristics of managers and political and administrative leaders has been studied in considerable depth (Damanpour \& Schneider, 2008; Gould-Williams, 2004, Walker, 2007), bringing to light the particular influence of each type of actor on the dynamics of innovation in public organizations. A third group of studies, growing in number as researchers become more active in this area, has focused on analyzing the influence of the perceived characteristics of innovation on its process of adoption and diffusion in the public sector (Boyne et al. 2005; Schneider, 2008). For example, Damanpour \& Schneider (2007) highlight the influence on the dynamics of innovation of factors such as the cost of innovation, its complexity, and its impact or relative advantage. The most recent research on the dynamics and processes of innovation address the theme of collaborative innovation and the role of actors and inter- and intra-organizational networks, as well as that of the link between public innovation and governance (Scupola \& Zanfei, 2016; Arundel et al., 2015). The meta-analysis of the literature by de Vries et al. (2016) on public innovation, covering over 180 articles published between 1990 and 2015, highlights two elements that legitimate the research problem. One is the predominance of conceptual and normative studies (and therefore a shortage of empirical knowledge and data on the processes of innovation) and the other is the quasi-inexistence of research on the links between different types of public 
innovation. Dubouloz \& Mattelin Pierrard (2017) confirm the importance of internal factors in the dynamic of innovation and more specifically, the influence of the characteristics and attributes of managerial innovations. Even though these studies, then, individually or collectively, have addressed the main determinants of public innovation, they all suffer from a common weakness, namely that each type of innovation is studied in isolation and any potential relation between one type and another is ignored (Damanpour, 2010; Damanpour \& Aravind, 2012; Walker, 2007). Thus, despite their theoretical and empirical contributions to the study of the determinants of public managerial innovation, they pay no attention to the mechanisms whereby innovations may influence each other (Ayerbe \& Fonrouge, 2005; Damanpour, 2014). Recent research, however, has brought to light the existence of potential relationships and interdependencies between different innovations in the same organization (whether these innovations are the same or different in type) (Le Roy et al., 2013, Battisti \& Stoneman, 2010). Nevertheless, empirical data and studies on the complementarity of innovations remain rare (Damanpour, 2014). This integrative approach (Dubouloz, 2013) or evolutionary perspective (Torugsa \& Arundel, 2015) is advocated by, among others, Roberts \& Amit (2003) and Damanpour (2010, 2014). It argues that innovations are neither mutually exclusive nor neutral relative to each other but, on the contrary, are linked by relations of mutual influence and therefore interdependent. The adoption of one type of innovation can facilitate or influence the adoption of other types of innovations (Torugsa \& Arundel, 2015). Even though these studies do not specifically address public managerial innovations, they nevertheless enable to postulate two types of links between innovations ${ }^{5}$.

Direct links: it is pushed forward a principle of reciprocal evolution or joint optimization between the social system, influenced by managerial innovation, and the technical system, determined by product innovation, with the evolution of one triggering a transformation of the other. Indeed, to be both efficient and effective, the development of new products and processes requires organizational change. The literature, on this point, is unanimous: managerial innovations are triggered by the technological innovations that precede them (Damanpour, 2014). Indeed, the former can be said to be at the service of the latter, facilitating their enactment and helping to realize their full potential (Damanpour, 2014). This dependent relationship (considered by Damanpour to be

\footnotetext{
${ }^{5}$ The limits of these studies, from the perspective of our research problem, concern, on one hand, the domain of the field work (the private sector) and, on the other hand, their research object, which is specifically limited to the analysis of the influence of technological innovations on managerial ones.
} 
reciprocal between technological innovations and managerial ones), which suggests a time dimension between the different types of innovation, has given rise to two main categories of temporal model (Ayerbe, 2006; Battisti et al., 2015): on one hand, the sequential model (Damanpour et al., 2009) and, on the other hand, the co-evolution model (Van de Ven \& Garud, 1994; Robert \& Amit, 2003) also known as the synchronous innovation model (Ettlie, 1988). If the first model supposes a sequential character and causal relations between the different innovations, it does not put forward any hierarchy or order of subordination between them. Thus, according to Damanpour (2014), technological innovations could as readily be determinants as consequences of organizational innovations. The analysis of innovations at 85 public libraries (from which the sequential model is derived) has shown that changes in the social structure of the organization, changes that resulted from managerial innovations, can subsequently lead to technical and technological innovations. The second category of model (the co-evolution or synchronous innovation model) is, for its part, an expression of the quasi-simultaneous adoption of different types of innovation that are complementary. This complementarity concerns the implementation of innovations as much as it does their performance outcomes. This second type of model is derived from the analysis of technological innovations of the product type in the manufacturing sector. However, the study by Walker et al. (2015) of 136 English local authorities shows a combined use of technological and administrative innovations.

Indirect links: The hypothesis of an indirect link between innovations is based on the notion of innovation capability and, more generally, on the concepts of organizational and dynamic capabilities (Teece 2007). From this perspective, innovation promotes, over time, the development of greater innovation capability, defined as the aptitude to develop new ideas, products and processes (Luo et al, 2005). It contributes to the establishment of new representations and behaviours (creativity, for example, or risk-taking) as well as interactions and learning that promote still greater innovation. Wynen et al. (2014) espouse this view. Their research shows that certain categories of public innovation, based on managerial autonomy, accountability and results-based evaluation, foster the development of an innovation culture, a culture that in its turn goes on to promote better performance and new innovations. By producing new organizational knowledge and by modifying internal behaviours and representations, innovation positively influences the organization's innovation capability. This indirect influence is suggested by Arundel et al. (2015) and Torugsa \& Arundel (2015) for whom managerial innovation, by redesigning 
activities and interactions, can be a source of learning and production of new knowledge, which in its turn goes on to engender a greater capacity to create and absorb new ideas. According to Lam (2005), managerial innovations prove to be essential for creating a climate favourable to creativity, learning and change. On the basis of these theoretical elements, two research propositions are formulated:

Proposition $\mathrm{n}^{\circ} 1$ : There is a direct link between managerial innovations implemented over time in the same public organization.

Proposition $\mathrm{n}^{\circ} 2$ : There is an indirect link between managerial innovations implemented over time in the same public organization.

In the next section, the empirical research, focused on local government bodies, will therefore investigate the nature of direct and indirect links between managerial innovations. The originality and interest of this study resides in the exploratory analysis of the potential links and interactions between different categories of public managerial innovations.

\section{Research methodology}

Given the complexity of this subject and the shortcomings of the existing research, an exploratory approach is adopted and a qualitative methodology based on multi-site case studies is deployed (Yin 2008). This approach is all the more appropriate in that the research attempts to characterize a complex phenomenon via its recursive causalities but also via its temporal dimensions. The case study enables one to account for "the historical, contextual and circumstantial dimensions of the phenomenon under study" (Giroux, 2003, p.45) and, thanks to the wide variety of data collected, makes it possible to gain an in-depth understanding of a complex phenomenon (Hlady-Rispal, 2002). It is a matter, then, of understanding the temporal sequence of different types of managerial innovation and direct-indirect influence's relations between them. In order to triangulate the data, three sources were used: primary data, secondary data, and data derived from action-research observations. The definition of relatively general propositions enables to structure the data collection and analysis while, at the same time, leaving 
open the possibility for the emergence, during fieldwork, of themes and categories of analysis related to the research questions.

From the data collection tools potentially available for case-study research (Yin, 2008), three are chosen:

- The interview: the primary source of data in case $n^{\circ} 1$ and the complement of observations in case $n^{\circ} 2$. A dozen semi-structured interviews were conducted and recorded, lasting two hours on average, with political administrators, directors general, management controllers and operations managers. The interview guide, drawn up after the literature review, addressed the context of innovation, its nature and characteristics, and the relations between innovation and organizational context.

- Participant observation: a complement to data collection in case $n^{\circ} 2$.

- Archival research and documentation review: enable to complement and corroborate the information obtained from the interviews. These primary sources (annual reports, minutes of meetings, intranet files, etc.) enabled us to make a more robust validation of the other sources.

These sources were chosen in accordance with the goals to establish the chronology of innovations and explain the links between them. The interviews allowed to obtain a wealth of information on subjects that included technical content requiring further explanation, and in this regard the interactive nature of the interview format facilitated data collection. However, as interviews entail a risk of bias, mainly to do with memory, a documentation review was used in order to limit this risk and enrich information.

For the fieldwork, a theoretical sampling (Yin, 2008) was drew on : the selected organizations had already carried out a range of managerial innovations over time and therefore were likely to provide relevant information to the phenomenon under study (Hlady-Rispal, 2002). To present the results two cases are used ${ }^{6}$ : first, a metropolitan

\footnotetext{
${ }^{6}$ The difference in data collection between the two cases is explained by the time spent in each local authority: Case 1 corresponds to a metropolitan administration and smaller local authorities where the research was conducted in different phases with the management control department, whereas Case 2 is an EPCl with different local authorities where it was possible to do field work with continual involvement over the long term with numerous actors. These two approaches to data collection correspond to the recommendations made by De Vries et al. (2016) on the need for research conducted on site in order to gain a real understanding of the process of
} 
administration that for over ten years has regularly initiated organizational changes; second, a public administrative structure devoted to inter-municipal cooperation known as an $\mathrm{EPCl}$ (établissement public de coopération intercommunale) that has recently enacted managerial innovations. These two cases represent the four forms of managerial innovation identified in the previous typology (Table 1, above). Indeed, case 1 illustrates a local process innovation that is related to a comprehensive process innovation and to a comprehensive structural innovation, while case 2 addresses a comprehensive structural innovation influencing a comprehensive process innovation. These cases enable the analysis of the variable "extent of change", with the passage from the local to the comprehensive level, as well as the variable "nature of the managerial innovation", with the passage from the structural to the process dimension. These cases are instrumental in nature, as defined by Stake (1995), but also representative and fully relevant to the research problem.

\begin{tabular}{|c|c|c|}
\hline & $\begin{array}{c}\text { Case } \mathrm{n}^{0} \mathbf{1} \\
\text { Metropolitan Administration }\end{array}$ & $\begin{array}{c}\text { Case } \mathrm{n}^{\circ} \mathbf{2} \\
\mathrm{EPCl}\end{array}$ \\
\hline Scope & $\begin{array}{l}\text { City, metropolitan community, CSSP } \\
\text { (central social services provider) }\end{array}$ & $\begin{array}{l}\text { Group of } 14 \text { municipalities (local } \\
\text { authorities) }\end{array}$ \\
\hline $\begin{array}{l}\text { Relations between elected } \\
\text { representatives and } \\
\text { administrative personnel }\end{array}$ & Regular, fairly consensual & $\begin{array}{l}\text { Regular, good between elected } \\
\text { representatives and municipalities }\end{array}$ \\
\hline $\begin{array}{l}\text { Level of innovation } \\
\text { experience }\end{array}$ & $\begin{array}{l}\text { High: numerous organizational } \\
\text { changes since the mid-1980s }\end{array}$ & $\begin{array}{l}\text { Limited: first major innovation is the } \\
\text { one under study }\end{array}$ \\
\hline Data collected & $\begin{array}{l}\text { Internal documents, interviews with } \\
\text { Services Directorate, controllers and } \\
\text { evaluators, observations (equivalent } \\
\text { to } 3 \text { days) }\end{array}$ & $\begin{array}{l}\text { Internal documents, participation in } \\
\text { meetings with elected representatives } \\
\text { and administrative staff, action research } \\
\text { observations (equivalent to } 20 \text { days), } \\
\text { and one hour with each actor to gain an } \\
\text { understanding of the structure and to } \\
\text { focus on the main changes to be } \\
\text { initiated with them. }\end{array}$ \\
\hline $\begin{array}{l}\text { Characteristics of } \\
\text { respondents }\end{array}$ & $\begin{array}{l}5 \text { interviewees: a political } \\
\text { administrator, a director general, } \\
\text { two management controllers, a } \\
\text { project manager }\end{array}$ & $\begin{array}{l}\text { Recorded Interviews with a mayor, a } \\
\text { services directorate, a manager. } \\
\text { Meetings with: president and director } \\
\text { general, management controller and } \\
\text { main department controller, mayors of } \\
\text { the towns that are part of the } \\
\text { organization, and agents (civil servants) }\end{array}$ \\
\hline
\end{tabular}

Table 2: The cases and the data collected

public innovation. Also, in relation to the research problem, the two cases are more complementary than comparative in purpose. 
The analysis of the data is largely based on the recommendations of Miles et al. (2013) and the methodology used by Ayerbe (2006), namely a preliminary analysis during an exploratory case to obtain a first-level coding (EPCI -A, not presented here), subsequently enriched to produce a thematic coding used in the interview guides. The guides addressed three themes: the nature of the innovations, the determinants and the roles of the actors, and the direct and indirect effects of the innovations. In order to bring regularities to light, the general analytical approach was based on an intra- then an inter-site analysis. Various presentation formats suggested by Miles et al. (2013) were developed (a chronological matrix of the innovations, a matrix of the relations between the innovations, a matrix of the actors involved in the innovations) and then, in order to verify the understanding of the field, were presented to the actors. This approach, then, was a semi-inductive one, with research propositions derived from the literature and a pre-coding derived from the exploratory case, leading to first- and second-order categories. The results obtained in each case are presented in a three-point format: (1) the socio-political and economic context and the expectations and objectives of the local actors; (2) the description of the innovations and their chronology (including a longitudinal diagram); (3) the description of the links and interdependencies between innovations.

\subsection{Presentation of the data for case $n^{\circ} 1$}

Case $n^{\circ} 1$ is that of a big French city that, in 2010, chose to change its accounting information system (AIS) in order to obtain an analytical view of the full scope of its public policies (covering the metropolitan community and the CSSP). In 2012, the analytical nomenclature was validated by the mayor. In 2014, as a result of the elections, a new team took office and, with a view to cutting costs and clarifying its actions, it enacted a "Public Policy Review" (PPR). This strategic initiative would draw on the research that had been undertaken on new accounting software, software that would have to comply with new regulations. The meetings concerning the AIS began in the city municipality in 2010. In 2012, the metropolitan community and the CSSP began cooperating, which led the administrative services and the elected representatives to work together on identifying opportunities for mutualizing services between the three structures. What is innovative here is having a single information system for three structures and a multi-dimensional, collaborative management system. Following the 2014 elections, the 
new leadership team (the mayor and the General Manager) completed this project, which had fully mobilized the different departments of each structure, and developed a new strategic management system, the Public Policy Review.

According to the administrative director, "PPR was a natural extension of the work on the AIS", but for the political actors (mayors) "it was a new challenge".

The municipality thus innovated first by deploying its new AIS (a unified framework for three structures, built collaboratively, without external assistance), then innovated again by developing its PPR management system (a comprehensive managerial innovation) that enables, via the management dialogue process, multi-dimensional strategic thinking (incorporating the political, administrative and constituent perspective in every one of the three structures' policies) with a more prospective, long-term horizon.

The political actors championed these initiatives (they launched the idea and were present during its enactment) and the administrative personnel relayed the new orientation.

The management controller explained: "It is the former mayor and the director general who moved the new accounting and financial information system forward into the different organizational structures. And it is the new mayor and director general who moved the PPR idea forward, enabling us to obtain an overall view of the actions across the whole territory from a strategic, less political perspective ".

The top-down approach, in this AIS project, was paralleled with a bottom-up one, since the service departments contributed ideas during the numerous scheduled meetings. To this political and administrative championing, it must be noted that the city municipality, the centre of the metropolitan community, had considerable experience of innovative projects. Indeed, it initiated changes in one of the French state's accounting directives, initiated innovative cost accounting methods that were adopted by a regional body (recognized by the Court of Auditors and by two national prizes for local-authority innovation), and initiated inter-municipality sporting and cultural projects, all of which gave rise to individual and collective representations favourable to the innovations. 
According to the director general and confirmed by the management controller, "the new information system enables us to standardize the presentation of our accounting and financial data for the three structures in a holding company framework. This made it possible for different teams to work together on projects and to have a common vision of the major issues in the field".

Table 3 shows, via the chronology of the innovations (the AIS followed by the PPR and the "management and performance dialogues"), the links between the local and comprehensive innovation on one hand and the process of structural innovation on the other.

In terms of the table 1 typology, the change of AIS and the mutualisation between the three structures can be classified as a local instrumental innovation, while the strategic initiative is a comprehensive process innovation. The leadership team whose mandate ended in 2014 had initiated the technological change (accounting and budgetary software) and the mutualisation of nomenclature by structure (reorganization of public policies) and had also envisaged the public policy initiative. In 2015, the new team implemented the AIS, implemented the mutualisation of services in the three structures and, as a supplementary layer toward inter-municipal cooperation, took up the PPR initiative with its objective-analysis trees for each department. The team leveraged the interdepartmental partnerships on the harmonization of concepts and terminologies to obtain a single policy framework for the three structures, the consolidated approach thus overriding an approach by individual structure. As the management controller pointed out, "PPR facilitated cross-functional information and enabled the perception of the three structures at the group level". The chairman of the metropolitan area (the mayor of the city centre) added: "The new approach now enables us to have meetings where we advance political and administrative viewpoints on the territorial strategy to be pursued".

The PPR initiative continued the approach begun with the same authorities, namely the mayor (who is president of the metropolitan community and leads the "city municipality-metropolitan community-CSSP" grouping) and the general manager (the project manager in this administration). 
Concerning the transformations generated by the first innovation that influenced, from an operational point of view, the adoption of the second one, the consolidation of the AIS of the "city municipality-metropolitan community-CSSP" grouping had the following direct effects (according to the director general and an audit by the management control department in 2013):

- the collection and presentation in a standard format of "horizontal" data (covering all three structures);

- the mutualisation of resources, resulting in cost savings;

- $\quad$ the experience of collaborative work between the three partner structures;

- changes in collective representations (interdependencies between issues) and in behaviours (collaboration and the pursuit of consensus).

These changes favoured the enactment of the second innovation desired by the new leadership team, the strategic PPR. As a managerial innovation, it drew on the resources of the actors promoting the project (political initiative of the elected representatives; experience of the administrative personnel). It also leveraged the technical and organizational knowledge acquired over the years of cooperation between the three structures. In addition, the metropolitan community's management advisory service provided methodological know-how and the elected representatives drew on their experience of partnership with their administrative counterparts.

The strategic PPR innovation also enabled, as noted in the city's 2016 annual report (reviewing the year 2015), "horizontal [inter-municipal] strategic thinking by policy and centre of responsibility" that, thanks to the "management and performance dialogues", promotes innovation in the decision-making process. These dialogues are monthly meetings led by the management advisory service; they address the planning of investment projects and operational and human resource issues for the mutualized, three-structure group. In parallel, the PPR initiative enables a consideration, in operational terms, of the new data to be consolidated. Thus, operational innovation concerning the AIS followed by a second, this time organizational, innovation, the PPR, enrich each other. Indeed, the IS, consolidated around the three structures, and the PPR initiative enable an enrichment of reflection during the management meetings, and in their turn these meetings, via the cross-fertilization between the different domains of expertise present, enable the fine-tuning of the IS by offering new data, more prospective in nature. Table 3 presents a synoptic view of the interrelations between these innovations. 


\begin{tabular}{|c|c|c|l|}
\hline & Phase 1 & Phase 2 & \multicolumn{1}{c|}{ Phase 3 } \\
\hline $\begin{array}{c}\text { Innovation in } \\
\text { process and } \\
\text { instruments }\end{array}$ & $\begin{array}{c}\text { (1) AIS (2012) } \\
\text { (Local } \\
\text { innovation) }\end{array}$ & & $\begin{array}{l}\text { (3) Continuous improvement of the } \\
\text { consolidated AIS across the 3 structures } \\
\text { (2015-2016); “management and } \\
\text { performance dialogues" (2016) facilitating } \\
\text { horizontal (inter-municipal), prospective } \\
\text { strategic thinking. (Comprehensive } \\
\text { innovation) }\end{array}$ \\
\hline $\begin{array}{c}\text { Structural } \\
\text { innovation (mode } \\
\text { of organization) }\end{array}$ & $\begin{array}{c}\text { (2) PPR (2014) } \\
\text { (Comprehensive } \\
\text { innovation) }\end{array}$ \\
\hline
\end{tabular}

Table 3: Links between the managerial innovations (case $n^{\circ} 1$ )

\subsection{Presentation of the data for case $n^{\circ} 2$}

Case $\mathrm{n}^{\circ} 2$ is that of an EPCl (établissement public de coopération intercommunale), a public administrative structure devoted to inter-municipal cooperation, in this case a community of 14 districts across a semi-rural territory. In 2014, the elected representatives of the EPCl wanted to move from a structure devoted to big projects to one focused on services, and thereby to attain a real complementarity between the services provided by the 14 districts. In early 2015, during the implementation of the EPCl's first mutualisation scheme, the service structures began working more closely together. Under the impetus of the elected representatives that cooperation has since broadened, leading in the summer of 2015 to a consideration of a territorial project and, in 2016, a second mutualisation scheme. Managerial innovation, pertaining to the new collaborative mode of working and the new way of elaborating the territorial strategy, emerged with the drafting of the first mutualisation scheme. The experience gained during these exchanges thus facilitated the development of new projects (see Table 4 for the chronology). 


\begin{tabular}{|l|l|l|l|l|}
\hline & \multicolumn{1}{|c|}{ Phase 1 } & Phase 2 & \multicolumn{1}{c|}{ Phase 3 } & \multicolumn{1}{c|}{ Phase 4 } \\
\hline $\begin{array}{l}\text { Innovation in } \\
\text { process and } \\
\text { instruments }\end{array}$ & & & $\begin{array}{l}\text { Mutualisation } \\
\text { scheme V2 and } \\
\text { implementation of a } \\
\text { territorial project } \\
\text { (mid-2016) } \\
\text { (comprehensive } \\
\text { process innovation) }\end{array}$ & $\begin{array}{l}\text { Enlargement of } \\
\text { territory (EPCI } \\
\text { merger) and work on } \\
\text { territorial project } \\
\text { (early 2017). Work on } \\
\text { an internal } \\
\text { regulations project } \\
\text { and a governance } \\
\text { charter } \\
\text { (comprehensive } \\
\text { process innovation) }\end{array}$ \\
\hline $\begin{array}{l}\text { Innovation in } \\
\text { structure (mode of } \\
\text { organization) }\end{array}$ & $\begin{array}{l}\text { Mutualisation } \\
\text { scheme (2015) } \\
\text { (comprehensive } \\
\text { structural } \\
\text { innovation) }\end{array}$ & $\begin{array}{l}\text { Setting up specific } \\
\text { meetings (2015) and } \\
\text { legitimation of } \\
\text { situations via } \\
\text { reference document } \\
\text { (local structural } \\
\text { innovation) }\end{array}$ & & \\
\hline
\end{tabular}

\section{Table 4: The links between the different managerial innovations (case $n^{\circ} 2$ )}

The innovation, in this case, has to do with to the mutualisation scheme, which is an obligatory document without any precise methodological framework; it enables the questioning of actions or activities already enacted in the $\mathrm{EPCl}$, actions or activities that could be mutualized. Regarding activities that have not yet been mutualized, the question of processes arose and a modernization of the organization, especially via a process of sharing and collaboration, was sought. This initiative led the $\mathrm{EPCl}$ to organize numerous work groups made up of different actors from the local authority, namely elected representatives and administrative personnel from the EPCl and the district administrations. Observations and meetings show that for many municipal agents, the EPCI was seen as being distant from everyday problems, dealing with matters more complex than municipal ones, and this sense of structural distance put a brake on collaborative work.

As the municipal agents in the IT department explained, "We have mutualized things, be we lack a sense of direction and a clear political vision"; the Cultural Affairs department added: "We discover things on a piecemeal basis, as the projects move forward". 
The opportunity to meet and exchange views while preparing the mutualisation schemes enabled the actors to not only bond with each other, but also, they affirmed, to give meaning to municipal and inter-municipal action as they addressed the question of territorialization.

Following on from the mutualisation scheme, all the meetings and commissions (on the validation and follow-up of the initiative, on its technical aspects), produced numerous local ideas, and so the need was felt to structure the ideas in a comprehensive framework. At the same time, territorial diagnostics were undertaken that brought to light possibilities for future development and highlighted the lack of a comprehensive strategic project for the EPCI.

Political personnel recall: "We had reached a point where we had to do a thorough review, clear the deck and question the rules of the game" (mayor of L.); "Too many questions came up without any answers for us to go ahead and build" (mayor of A.).

A blockage in the operational dimension had revealed the need for a clearer structuring of public policies, policies on which strategic management could be based. One such example, recommended by one of the commissions, is the "Missions, Programmes, Actions" initiative, in which the operational level orients and influences the strategic level. A first innovation, of the comprehensive structural type, concerned legal obligations. It led the actors to raise questions about values, the possibilities for change, and the types of change desirable for the territorial authority. It also led them to think through the territory's development from a more strategic and prospective point of view (comprehensive structural innovation). In itself, the strategic approach was innovative, since it had never been used or even discussed in the EPCI before.

As the Director General of Services emphasized, "the collaborative work on the first mutualization scheme enabled people who weren't used to meeting up with each other to engage in dialogue and become comfortable with one another, to work jointly on things. It was afterwards that the need appeared to rework the road map in order to situate actions in a broader perspective, more thoughtout" (extract from the house magazine, May 2016).

The work on the territorial project led these same actors, one year later, to work again on the operational dimension in order to draft a second version of the mutualisation scheme (certain EPCls, in contrast, have never 
drafted such a document). This second version of the scheme was produced at the same time as the consolidation of the territorial project took place. The project, for its part, was elaborated around this dynamic and drew on the work already realized. Because they influence and enrich each other, these two innovations can be considered as joint innovations.

At the conclusion of the territorial project and the new mutualisation scheme, a merger with four other EPCls took place. The participative, structuring character of the first innovations brought about, according to the managers interviewed, a federative dynamic across the territory. This enabled the launch of new innovative projects, currently underway, including the drafting of a governance charter and the elaboration of a new territorial project and another mutualisation scheme.

\section{Discussion of the findings}

This research highlights, in both cases under study, the existence of links and relations of influence between the innovations implemented at different times in the same organization. In the first case, a comprehensive process innovation of a technical nature (an information system) influences the adoption of a structural, more wide-ranging innovation. In the second case, it was an organizational transformation to do with structure that led to the adoption of a second managerial innovation, this time of a managerial nature. The study of effects and impacts shows that the first innovation creates conditions favourable to the emergence of a second innovation, and this at two levels. Firstly, by generating an incentive to innovation and change; secondly, by positively influencing the innovation capability of the actors concerned. Analyses revealed, following the example of Walker (2007) and Damanpour (2010), the positive role played in the public sector by past innovations in the dynamic of adoption and diffusion of follow-on innovations.

Concerning the positive impact on the incentive to innovation, the first innovations generate changes that very quickly find themselves limited in their implementation unless other changes are enacted in a complementary fashion. The necessity to optimize a technical or structural innovation leads to a second, higher-order innovation. 
For example, in case $n^{\circ} 2$, where the task was to group services and structures, the absence of a clear project made it impossible for mutualisation to progress. Indeed, the existing projects were not consistent with each other and the agents did not know to what dynamic they should subscribe. The reorganization of community services and competencies thus required the elaboration of a strategic framework. It was the actors' shared recognition of the limits of the initial innovation that, firstly, contributed to their desire to formulate a strategic project, and secondly, generated innovative, resolute and proactive behaviour to that end. An innovation, then, can build up pressure and create an incentive to launch another innovation, one that would be complementary to it and participate in its implementation. This interdependence is similar to the concept of complementary or linked innovation highlighted by a number of authors, including Khanagha et al. (2013) and Walker (2007). The adoption of a stream of innovations and the fact of managing pairs or groups of innovations simultaneously leads to higher performance, thanks to the reinforcement and synergy effects between them (Damanpour et al., 1989; Damanpour \& Aravind, 2006).

This research also shows that innovation, especially when it modifies actors' representations, has a positive impact on innovation capability. Thus, in case $n^{0} 1$, strategic innovation was facilitated by the evolution of frameworks of thought and representation generated by the first innovation. The fact of having exchanged views on "horizontal" elements that concerned all services (during phase 1 of the modification of the AIS) enabled a rethinking of the typology of public policies (phase 2) and, in light of the success of these first innovations, to organize "performance dialogue meetings" (phase 3), where the actors could discuss both "vertical" and "horizontal" themes. The integration of a more systemic, horizontal perspective on organizational issues was fostered by dialogue between all the actors involved, including the leadership team. Taking into account the interdependencies and complementarities between local public policies and issues legitimates the adoption of an innovation concerning public policy definition and structuring. Thus an operational and technical process innovation fostered a collective awareness of the necessity to change and therefore to innovate more comprehensively and strategically. Moreover, as the actors had the opportunity to communicate with each other and express their creativity, the collaboration brought about by the first innovations led not only to an exchange of information and a sharing of knowledge, but also to the generation of new knowledge and shared diagnoses. 
These results are in line with those of Wynen et al. (2014) and Verhoest et al. (2007), who demonstrate the positive influence of certain managerial innovations on the development of an innovation-oriented culture. The transformation of organizational culture, via a modification of the dominant values and representations, results in a climate more favourable to innovation. These changes, it must be noted, are due largely to the collaborative and interactive character of the innovation process.

More than triggering factors, then, innovations are facilitators, factors that create conditions favourable to more wide-ranging innovations. Past innovations, as antecedents to the dynamic of future innovation, appear to have a more indirect and more peripheral influence than the organizational and environmental antecedents traditionally considered by the literature. Indeed, past innovation is more of a facilitating factor than a direct determinant of innovation. Nevertheless, its influence on the dynamic of innovation is far from negligible; for example, it contributes to removing a number of cultural and behavioural brakes on change. In case $n^{\circ} 2$, for instance, elected representatives and public managers have taken an increasing assumption of responsibility and risk. These actors legitimated and championed the innovation initiative in their organization and contributed to overcoming the constraints carried over from previous modes of operating.

The demonstration of indirect links between innovations, an approach that draws on resource-based theories, is particularly clear in case $n^{\circ} 2$. Indeed, the case shows that managerial autonomy, accountability and evaluation, as well as the ability to perceive both the internal and external environments differently, promotes the development of an innovation that follows on from an initial one. This result can be qualified with observations from case $n^{\circ} 1$, where it was the know-how developed during a first innovation (the single information system for three structures and a management system that obliged the actors to collaborate) that would be redeployed in a second, related innovation (the policy review conducted at the level of the group of three structures). The process of innovation thus follows a rationale of proximity and reveals a direct link between the innovations studied. However, this case is particular, since the experience of organizational change accumulated by the metropolitan community endowed 
it with a managerial innovation capability. This finding thus also confirms resource-based theories and the observations from case $\mathrm{n}^{0} 2$.

Another point revealed by this research is the relations of interdependence and influence between innovations. It thus confirms the findings of Walker $(2006,2007)$ as well as those of Battisti et al. (2015) regarding the relatively complex nature of the links that arise between different types of innovation. Thus, if one innovation can promote the adoption of another innovation, the second one can in its turn influence the dynamic of diffusion and the nature of the first innovation. Case $n^{0} 2$ shows that if mutualisation led to the formulation of a strategic project, this project, in its turn, modified the process of grouping activities and services together, broadening it. This result, then, does not match the linear model of the innovation dynamic that poses a succession of generic steps, from awareness to routinization (Rogers, 2003; Damanpour \& Wischnevsky, 2006), but, on the contrary, argues that the innovation process, with its many interdependencies between different innovations, is long, complex and recursive (Torungsa \& Arundel, 2015).

As it has been shown, an innovation dynamic of the evolutionary type was confirmed in this research. Indeed, for the organizations studied, it was observed a series of incremental changes generated by preceding innovations. Like the concept of the organizational path in organizational change theory, the dynamic of innovation is conditioned by preceding innovation choices and their trajectories (Teece 2007). The cumulative effect of incremental changes, changes derived from preceding innovations, serve as a basis for later innovations (Roberts \& Amit, 2003). Indeed, if the dynamic of innovation is influenced by past choices, it never stops modifying actors' behaviours and representations, and thus continues to shape future innovation capability.

Finally, these findings confirm the results of Dubouloz (2013), which show that the positive perception of innovation together with resource endowments such as time and skill are key determinants of managerial innovation. On the managerial level this research, by highlighting the role of resources (particularly human resources) and perception (the values and representations regarding innovation) in generating innovation, offers 
an analysis that enables a better understanding of the process of managerial innovation and the factors that promote it.

\section{Conclusion}

The objective of this research was to explore and analyze the links between innovations implemented in the same organization. This article started with the observation of the nature of the links between the implementation of an innovation and the subsequent adoption of another innovation. The findings from the two case studies show that the enactment of one type of innovation can lead to the adoption of another innovation. More precisely, managerial innovation is a determinant that promotes the emergence of other innovations by generating an incentive to innovate and by positively influencing the innovation capability of the actors concerned. Via this indirect link between innovations, a link that augments innovation capability, the cases demonstrate learning effects and resource mobilization that allow one to consider an innovation in an organization as an antecedent to a future innovation.

Further research could usefully focus on the characterization and analysis of the innovation learning process, identifying its individual and collective components. The process of collecting rich and longitudinal qualitative data is relevant, but suggests other determinants of innovation not studied here because peripheral to the research problem. Thus organizational determinants such as the structuring of organizational memory (accumulation of innovative experiences), the weight of internal communication, human factors such as leadership style, and environmental factors such as institutional and mimetic isomorphism in reference to New Institutionalism can enrich the nature of the determinants. The study of these structuring and explanatory factors of the implementation and adoption of an innovation can be undertaken via the pursuit of case analysis over a sufficiently long period. Finally, analysis of the influence on the organization's innovation dynamics of past failures and attempts at innovation that fell short would constitute a complementary extension of this research. 


\section{Bibliography}

Arundel A., Casali L., Hollanders H. (2015). "How European public sector agencies innovate: The use of bottom-up, policy-dependent and knowledge-scanning innovation methods", Research Policy, Vol 44, $n^{\circ} 7$, p.1271-1282.

Ayerbe, C. (2006). "Innovations technologique et organisationnelle au sein des PME innovantes: complémentarité des processus, analyse comparative des mécanismes de diffusion", Revue Internationale PME, Vol. 19, n¹, p.9-34.

Ayerbe, C., Fonrouge, C. (2005). "Les transitions entre innovations : études de cas et proposition d'une grille d'interprétation ", Finance Contrôle Stratégie, Vol.8, n², p.39-64.

Battisti G., Colombo M.G., Rabbiosi L. (2015), "Simultaneous versus sequential complementarity in innovation adoption: the case of technological and organizational innovations in the sphere of design". Industrial and Corporate Change, Vol. 24(2), pp. 345-382

Battisti, G., Stoneman, P. (2010). "How innovative are UK firms? Evidence from the Fourth UK Community Innovation Survey on synergies between technological and organizational innovations. British Journal of Management, Vol.21 (No.1). pp. 187-206.

Birkinshaw, J.; Hamel, G.; Mol, M.J. (2008), " Management Innovation ", Academy of Management Review, Vol. 33, n4, p. 825-845.

Bocquet, R., Dubouloz, S. (2015). "Fariborz DAMANPOUR : De l'innovation dans les organisations à I'innovation managériale", in E. E. Collection Les Grands Auteurs (éds.), Les grands auteurs en management de l'innovation, Dirigé par Thierry BURGER-HELMCHEN, Patrick COHENDET et Caroline HUSSLER.

Bouckaert, G.; Halligan, H. (2008). Managing Performance- International Comparisons, Routledge.

Boyne, G. A. Law J S., Walker, R. M. (2005), " Explaining the Adoption of Innovation: An Empirical Analysis of Public Management Reform ", Environment and Planning: Government and Policy, Vol.23, $\mathrm{n}^{\circ} 3$, p. 419-435.

Damanpour, F. (1987), "The adoption of technological, administrative and ancillary innovations: impact of organizational factors", Journal of Management, Vol. 13, n³4, p. 675-688.

Damanpour, F. (2010). "An integration of research findings of effects of firm size and market competition on product and process innovations", British Journal of Management, Vol. 21, p.996-1010.

Damanpour, F. (2014), "Footnotes to Research on Management Innovation", Organization Studies, Vol. $35, n^{\circ} 9$, p. $1265-1285$.

Damanpour, F., Aravind, D. (2012), "Managerial innovation: Conceptions, processes, and antecedents", Management and Organization Review, Vol 8, n², p. 423-454. 
Damanpour, F., Walker, R. M., Avellaneda, C. N. (2009). "Combinative Effects of Innovation Types and Organizational Performance: A Longitudinal Study of Service Organizations", Journal of Management Studies, Vol 46, n4, p.650-675.

Damanpour, F.; Schneider, M. (2006). " Phases of the Adoption of Innovation in Organizations: Effects of Environment », Organization and top Managers", British journal of Management, Vol.17, p. 215-236.

Damanpour, F.; Schneider, M. (2008). « Characteristics of Innovation and Innovation Adoption in Public Organizations: Assessing the Role of Managers ", Journal of Public Administration Research and Theory, Vol.19, n³, p. 495-522.

Damanpour, F.; Szabat K A; Evan W M. (1989). "The relationship between types of innovation and organizational performance ", Journal of Management Studies, Vol. 26, n, p. 587-601.

Damanpour, F.; Wischnevsky D J. (2006). "Research on innovation in organizations: Distinguishing innovation generating from innovation-adopting organizations", Journal of Engineering and Technology Management, Vol. 23, n², p. 269-291.

Damanpour, F; Aravind, D. (2006). "Product and process innovation: a reveiw of organizational and environnemental dterminants", dans Jerald Hage \& Marius Meeus (Ed.), Innovation science and Instititional Change. A research Handbook: p. 38-65, Oxford University Press.

De Lancer Julnes, P. (2008), "Performance-Based Management Systems- Effective Implementation and Maintenance", Public Administration and Public Policy, CRC Press, 288 p.

De Vries, H., Bekkers, V., Tummers, L. (2016), « Innovation in the Public Sector: a Systematic review and Future Research Agenda, Public Administration, Vol 94, n¹, p. 146-166.

DiMaggio, P.J.; Powell, W.W. (1983). «The Iron Cage Revisited: Institutional Isomorphism and Collective Rationality in Organizational Fields ", American Sociological Review, Vol. 48, n², p. 147-160.

Dubouloz, S. (2013). "Les barrières à l'innovation organisationnelle : le cas du Lean Management", Management International, Vol 17, $n^{\circ} 4$, p. 121-144.

Dubouloz, S., Mattelin Pierrard, C. (2017). "Mieux comprendre le phénomène d'adoption d'une innovation managériale grâce aux caractéristiques et représentation sociale des dirigeants. Le cas de l'entreprise libérée ", Conférence AIMS 2017 - Lyon du 7 au 9 juin.

Ettlie J. E. (1988). Taking charge of manufacturing: How companies are combining technological and organizational innovations to compete successfully. Jossey-Bass Inc., Publishers.

Giroux, N. (2003). "L'étude de cas ", dans Y. Giordano (Coord.). Conduire un projet de recherche - Une perspective qualitative. Paris: Editions EMS, Collection Les Essentiels de la Gestion, p. 41-84.

Gonzalez, R., Llopis, J., Gasco, J. (2013), "Innovation in public services: The case of Spanish local government", Journal of Business Research, Vol. 66, n¹0, p. 2024-2033.

Gould-Williams, J. (2004). "The Effects of High Commitment HRM Practices on Employee Attitude: The Views of Public Sector Workers", Public Administration, Vol. 82, n¹, p.63-82. 
Hijal-Moghrabi, I. (2017). "The Current Practice of Performance-Based Budgeting in The Largest UsS Cities: An Innovation Theory Perspective", Public Performance \& Management Review, Vol 40, n4, p. 652-675.

Hlady-Rispal, M. (2002). La méthode des cas - Application à la recherche en gestion. Bruxelles: De Boeck Université, Collection Perspectives Marketing.

Jung, C. H., Lee G. (2016), “Organizational Climate Leadership, Organizational Size and Aspiration for Innovation in Government Agencies", Public Performance \& Management Review, Vol 39, p. 757-782.

Khanagha, S., Volberda, H., Sidhu, J., I. Oshri. (2013), "Management Innovation and Adoption of Emerging Technologies: The Case of Cloud Computing", European Management Review, Vol 10, n¹,p.5167.

Lam, A. (2005). managerial innovation. In J. Fagerberg, D. C. Mowery \& R. R. Nelson (Eds.), The Oxford handbook of innovation (pp. 115-147). Oxford: Oxford University Press.

Le Roy, F., Robert, M., Giuliani, P. (2013). "L'innovation managériale », Revue Française de Gestion, Vol 6, n²35, p. 77_90.

Luo L., Kannan P.K., Besharati, B., Azarm S. (2005). Design of robust new products under variability: Marketing meets design. Journal of Product Innovation Management, Vol 22, n², p.177-192.

Lux G., Petit, N. (2016)." Coalitions of Actors and Managerial Innovations in the Healthcare and Social Healthcare Sector", Public Organization Review, Vol 16, p.251-268.

Miles, M.B., Huberman M., Saldana, J. (2013). Qualitative Data Analysis, 3rd Ed., Sage, 381p.

Mol, M. J., Birkinshaw J. (2014). "The Role of External Involvement in the Creation of Management Innovations", Organization Studies, Vol 35, n 9, p. 1287-1312.

Poister T H., (2010) "The future of strategic planning in the public sector: linking strategic management and performance", Public Administration Review, Vol. 70, s1, p. 246-254.

Rivenbark, W C., Fasiello R., Adamo S. (2016), “Moving Beyond Innovation Diffusion In Smaller Local Governments: Does Performance Management Exist?", Public Administration Quarterly, Vol. 40, $n^{\circ} 4$. P.763-788.

Roberts, P W; Amit, R. (2003). "The Dynamics of Innovative Activity and Competitive Advantage: The Case of Australian Retail Banking, 1981 to 1995”, Organizational Science, Vol. 14, n², p. 107-122.

Rogers, E.M. (2003). Diffusion of innovations, New York: Free Press, 5ème ed.

Sapprasert, K., Clausen, T. H. (2012). "Managerial innovation and its Effects", Industrial and Corporate Change, Vol 2, n5, p. 1283-1305.

Schneider, M. (2007). "Do attributes of Innovative Administrative Practices influence their adoption? An exploratory Study of US local Government", Public Performance \& Management Review, Vol.30, n4, p.590-614.

Scupola, A., Zanfei, A. (2016). "Governance and innovation in public sector services: The case of the digital library", Government Information Quarterly, Vol 33, n², p.237-249. 
Shenhav, Y., Weitz, E. (2000). "The roots of uncertainty in organization theory: A historical constructivist analysis ». Organization, Vol 7, n³, p.373-401.

Sorensen, E, Torfing, J. (2011). "Enhancing Collaborative Innovation in the Public Sector", Administration \& Society, $\mathrm{Vol} 43, \mathrm{n}^{\circ} 8$, p. 842-868.

Stake, RE. (1995). The Art of Case Study Research. Thousand Oaks, CA: Sage Publications

Teece, D J. (2007). "Explicating dynamic capabilities: the nature and microfoundations of (sustainable) enterprise performance", Strategic Management Journal, Vol. 28, n¹3, p. 1319-1350.

Tether, B. S., Tajar, A. (2008). "The organizational-cooperation mode of innovation and its prominence amongst European service firms", Research Policy, Vol 3, n4, p. 720-739.

Torugsa N., Arundel A. (2015). "The nature and incidence of workgroup innovation in the Australian public sector: Evidence from the 2011 State of the Service survey", Australian Journal of Public Administration, $\operatorname{Vol} 75, \mathrm{n}^{\circ} 2$, p.202-221

Vaccaro, I. G., Jansen, J. J. P., Van Den Bosch, F. A. J., Volberda, H. (2012), “Management Innovation and leadership: The moderating role of organizational size", Journal of Management Studies, Vol 49, n¹, p.28-51.

Van de Ven, A. H., Garud, R. (1994). "The coevolution of technical and institutional events in the development of innovation " in AC Baum and JV Singh (Dir) Evolutionary Dynamics of Organizations, NY, Oxford University Press, p.425-443.

Van de Ven, A. H., Rogers, E. (1988). "Innovation and organizations: critical perspectives", Communication Research, Vol. 15, p.632-651.

Van Dooren, W.; Thijs, N. (2010). "Paradoxes of Improving Performance Management (Systems) In Public Administration », EIPASCOPE, p.15-19.

Verhoest, K., Verschuere, B., Bouckaert, G. (2007). "Pressure, Legitimacy and Innovative Behavior by Public Organizations", Governance, Vol. 20, n³, p.469-497.

Volberda, H. W., Van Den Bosch, F. A. J. et Heij, C. V. (2013). "Management Innovation: Management as Fertile Ground for Innovation", European Management Review, Vol. 10, n¹, p.1-15.

Volberda, H. W., Van Den Bosch, F. A. J., Mihalache, O. R. (2014), "Advancing Management Innovation: Synthesizing Processes, Levels of Analysis, and Change Agents", Organization Studies, Vol. 35, n9, p. 1245-1264.

Walker, R, M., Berry, F, S, Avellaneda, C, N. (2015). "Limits on innovativeness in Local Government: examining capacity complexity and dynamism in organizational task environment", Public Administration, $\mathrm{Vol} 93, \mathrm{n}^{\circ} 3$, p. 663-683.

Walker, R. (2006). "Innovation Type and Diffusion: An Empirical Analysis of local Government ", Public Administration, Vol. 84, n², p. 311-335. 
Walker, R. (2007). "An Empirical evaluation of Innovation Types and Organizational and Environmental Characteristics: Toward a configuration Frameworks ", Journal of Public Administration Research and Theory, Vol. 18, n², p. 591-615.

Walker, R. M., Boyne J A. (2006). "Public management reform and organizational performance: An empirical assessment of the U.K. Labour government's public service improvement strategy", Journal of Policy Analysis and Management, Vol. 25, n², p. 371-393.

Wynen, J., Verhoest, K., Ongaro E., Van Thiel, S. (2014). "Innovation- oriented culture in the public sector, Public Management Review, Vol. 16, n¹, p. 45-66.

Yang, K., Hsieh J. Y. (2007), « Managerial Effectiveness of Governance Performance Measurement: Testing a Middle-range Model », Public Administration Review, Vol. 67, n5, p.861-878.

Yin, R.K. (2008). Case study research: design and methods, Newbury Park, CA: Sage Publications, 4th. ed. 